\title{
Barns rett til religionsfrihet
}

\begin{abstract}
This article discusses whether there is a tension between granting children freedom of religion and giving the parents the right to decide over the upbringing of their children. It presents what Norwegian law, which has incorporated several UN Human Rights conventions, has to say about this. It also discusses whether the interpretation presented can be in the best interest of the child. The last part addresses how parents can give their children a sound religious upbringing and still give them the freedom to choose their own faith.
\end{abstract}

Keywords: Rights of children and parents, Religious freedom, Religious upbringing,

Av RunE ØysteSE, 1958, 1.lektor ved NLA Høgskolen. Berlandsvegen 283, 5314 Kjerrgarden. E-post:ro@nla.no.

Religionsfrihet er vel etablert i Norge. Men hvordan arter denne friheten seg i praksis for barn? Og hvordan kan foreldre balansere sin rett til å velge oppdragelse for barnet og barnets religionsfrihet, slik at det blir til barnets beste? Dette er spørsmål som lever i den offentlige debatten. En diskusjon mellom Espen A. Hasle, tidligere leder av Normisjons barne- og ungdomsorganisasjon, og Jens Brun-Pedersen, pressesjef i Human-Etisk Forbund, kan gi et utgangspunkt til å se hvor ulikt en kan se på disse spørsmålene. I et intervju i Vårt Land 21. januar 2014 uttrykker Hasle bekymring for at «veldig mange voksne deserterer fra barns åndelige liv». (Omvik, 2014.) Han fortsetter: - Hvis man unnlater å overføre sin kristne tro, er det et svik mot barna. Vi har et ansvar som foreldre å gi barna det beste vi har funnet i livet - også med tanke på troen vår.

To dager senere protesterer BrunPedersen i et innlegg i Verdidebatt i samme avis:

Foreldre har ifølge foreldreretten en rett til a påvirke sine barn livssynsmessig. Rett, men ikke plikt. Det er også tillatt å utvise respekt for barns autonomi vedrørende livssynsvalg ved ikke å påvirke aktivt. At også flere religiøse foreldre ser ut til å vare tilbakeholdne med a påvirke barna på livssynsområdet, blir presentert som noe negativt i reportasjen. Mange $a v$ oss ser snarere det som et uttrykk for $ø k t$ respekt for barns integritet og selvstendighet og er glade for denne utviklingen ... Det som absolutt er viktig at vi foreldre gjør overfor våre barn, er å påvirke dem verdimessig. Vi bør lære dem om riktig og galt, om gjensidighet, medmenneskelighet, cerlighet, om solidaritet osv. (Brun-Pedersen. 2014a.)

Hasle argumenterer for at foreldre aktivt skal oppdra barna i det livssyn de mener er best. Han mener det er et svik å ikke gjøre det. Brun-Pedersen argumenterer for en livssynsmessig ikke-aktiv oppdragelse. Han mener det er mest respektfullt overfor barna at foreldre ikke bruker den retten de har til å påvirke barna livssynsmessig. Hvem har rett?

Spørsmålsstillingen berører mange fagområder. Pedagogikken, psykologien og jussen er blant dem, men også teologer, sosiologer og andre har noe å si når temaet er religiøs oppdragelse. I denne artikke- 
len skal vi i første omgang holde oss til hva loven sier om barns og foreldres rettigheter. Men loven sier også at spørsmålet om «barnets beste»¹ skal være et overordnet prinsipp. Derfor vil artikkelen også spørre om den forståelsen vi får av lovverket, kan forsvares ut fra barnets beste. Her vil vi trekke inn tekster fra forskjellige fagfelt, særlig religionspedagogisk faglitteratur.

Metoden i denne artikkelen er tekstanalyse; helhetsanalyse eller meningsanalyse for å gripe intensjonen i tekstene, del- eller begrepsanalyse for å oppdage nyansene mellom tekstene. Dette gjelder særlig de forskjellige lovtekstene.

I første del er det lovtekster som analyseres, med spørsmålene:

1 Hvordan forstås religionsfrihet for barn?

2 Hvordan beskrives foreldrenes rettigheter i forholdet til barns religiøse oppdragelse?

I andre delen blir spørsmålet:

3 Kan svarene som gis til de første spørsmålene, forenes med kravet om at «barnets beste» skal være et overordnet prinsipp?

Den siste delen vil gi noen eksempler på hvordan en religiøs oppdragelse kan ta vare på barnets rett til frihet.

Denne analytiske tilnærmingen har fordeler og ulemper. Lovene er slik det er, de er tilgjengelige for alle. Men utstrakt behandling av lovtekstenes forhistorie og virkningshistorie blir for omfattende for de rammene denne artikkel setter. Forhistorien kunne gitt mye kunnskap om intensjonene bak tekstene. Og domstolenes bruk av de forskjellige lovene er viktig for forståelsen av lovene. Utvalget av de andre fagtekstene er preget av at mitt fagfelt er religionspedagogikken. Samtidig ber $\emptyset-$ rer dette temaet mange fagfelt. $\AA$ få med de mest aktuelle tekstene samtidig som en får en balansert presentasjon av forskjellige syn, er en utfordring. I denne artikkelen vil temaet bli behandlet fra voksnes synsvinkel; først og fremst lovgivere og forskere. Hvordan barna og foreldrene opplever og vurderer sin egen (og sine barns) situasjon, ville være viktige bidrag inn i denne debatten. Men da måtte andre metoder vært tatt i bruk.

\section{Del I: Barn, ReligiøS frihet og OPPDRAGELSE I NORSK LOV}

I 1999 ble Menneskerettsloven vedtatt av Stortinget. Den gjorde flere menneskerettskonvensjoner ${ }^{2}$ til norsk lov. \$3 i Menneskerettsloven slår fast at konvensjonene har mer vekt enn andre lover: De skal «ved motstrid gå foran bestemmelser i annen lovgivning» (Lovdata. 1999). Konvensjonene er resultat av forhandlinger og dragkamper. Kilkelly skriver om Barnekonvensjonen (The Convention of the Rights of Children, heretter CRC) at denne dragkampen har ført til at formuleringene er blitt vage, tvetydige og så runde at de har begrenset verdi (Kilkelly. 2016. s. 245). Eva Brems, henviser til Van Bueren når hun skriver om utfordringene ved utformingen av konvensjonen:

1 Barnekonvensjonen eller CRC kaller «barnets beste» et grunnleggende hensyn (artikkel 3) som alltid må tas med i vurderingen av barnets rettigheter. (FN 1989).

2 I dag er fem konvensjoner inkludert i denne loven: Den europeiske menneskerettskonvensjonen av 1950, FNs konvensjon om økonomiske, sosiale og kulturelle rettigheter av 1966, FNs konvensjon om sivile og politiske rettigheter av 1966, FNs Kvinnekonvensjon av 1979, FNs Barnekonvensjon av 1989. 
Van Bueren notes that religious freedom for children has always been a problematic issue in international law, and that in the context of the CRC, disagreement over the extent of the rights, as applicable to children, risked obstructing the drafting and adoption of the entire Convention. (Brems. 2006. S.1)

Konvensjonenes til dels vage formuleringer til tross, de er forpliktende norsk lov.

Fokuset på menneskeretter ble forsterket i norsk lovverk i 2014. Da fikk vi et kapittel i Grunnloven kalt 'Menneskerettigheter'. Her blir det på nytt slått fast at konvensjonene nevnt i Menneskerettsloven fra 1999 er bindende.

Vi begynner med FNs menneskerettserklæring fra 1948 (UDHR) ${ }^{3}$. Erklæringen er ikke med i Menneskerettsloven, men den blir nevnt og anerkjent $\mathrm{i}$ innledningene til alle konvensjonene i Menneskerettsloven (Se Lovdata.1999), og de må forstås i sammenheng med UDHR fordi de ofte har lik eller lignende ordlyd. Det er særlig artiklene 18 og 26 som er aktuelle.

Enhver har rett til tanke-, samvittighets-og religionsfrihet. Denne rett omfatter frihet til a skifte religion eller tro, og frihet til enten alene eller sammen med andre, og offentlig eller privat, å gi uttrykk for sin religion eller tro gjennom undervisning, utøvelse, tilbedelse og ritualer. (FN 1948. Art. 18.)

Artikkelen begynner med «Enhver». Her er ingen utelukket. Artikkelen gir alle rett til å velge, skifte og utøve sin religion. «Undervisning» er et trosuttrykk på linje med tilbedelse og ritualer. Artikkel 26 har undervisning som tema. Alle har rett til å få undervisning. Undervisningen skal utvikle personligheten. Tredje punkt sier: Foreldre har fortrinnsrett til å bestemme hva slags undervisning deres barn skal få. Vi skal se hvordan disse rettighetene blir kopiert og bearbeidet $\mathrm{i}$ de konvensjonene som er tatt inn $\mathrm{i}$ Menneskerettsloven.

\section{Barnekonvensjonen}

Det er naturlig å begynne med CRC. Den ble vedtatt i 1989. FNs Barnekomité vokter over inkorporering av konvensjonen i medlemsstatene. CRC ble tatt inn $\mathrm{i}$ Menneskerettsloven i 2003. Artikkel 14 sier:

1 Partene skal respektere barnets rett til tankefrihet, samvittighetsfrihet og religionsfrihet.

2 Partene skal respektere foreldrenes, eventuelt vergenes, rett og plikt til å veilede barnet om utøvelsen av hans eller hennes rettigheter på en måte som er $i$ samsvar med barnets gradvise utvikling (Lovdata. 2003. To første avsnitt.)

Barnet har religionsfrihet. Foreldrenes rett og plikt blir beskrevet som «å veilede om utøvelse». Dette er altså en veiledning av praksis. Barnekomiteen sier i en kommentar med særlig fokus på de små barna:

Foreldre (og andre) bør oppmuntres til å gi «støtte og veiledning» på en måte som setter barnet $i$ sentrum, gjennom dialog og ved a opptre som forbilder, på en måte som styrker små barns evne til å utøve sine rettigheter, herunder retten til å delta (artikkel 12) og retten til tankefrihet, samvittighetsfrihet og religionsfrihet (artikkel 14). (Barnekomiteen. 2005)

CRCs 《veiledning om utøvelse» tolkes av Barnekomiteen også som et fokus på praksis: Barna skal få hjelp til å utøve, foreldrene skal samtale med barna og være forbilder i det å bruke sin religionsfrihet. 
Deltagelse blir poengtert, men ikke valgfrihet. Også andre artikler behandler barnets religion som gitt. CRCs artikkel 30 tar opp minoriteters rettigheter:

I stater hvor det finnes etniske, religiøse eller språklige minoriteter ..., skal et barn som tilhører en slik minoritet eller urbefolkningen, ikke nektes retten til ... å leve i pakt med sin kultur, bekjenne seg til og utøve sin religion, eller bruke sitt eget språk. ${ }^{4}$

«Sin religion» viser her til gruppens eller kulturens religion. Retten barnet har, er å utøve denne religionen. Vi skal senere se at tanken om at en er født inn i en religiøs sammenheng, også finnes andre steder i norsk lov. Dette forsterker opplevelsen av at religionsfrihet for barn er en frihet til å utøve 'sin religion'. Men friheten til å velge religion må likevel forstås som en del av religionsfriheten, fordi også barnekonvensjonen erkjenner UDHR og «er blitt enige om at alle har krav på de rettigheter og friheter som er fastsatt i〉 (denne) (Lovdata.1999. vedlegg 8, Innledning). Likevel kan CRCs formuleringer ses på som en begrensning av valgfriheten inntil barnets «gradvise utvikling» er kommet langt nok til at det kan ta fullt ansvar for et slikt valg uavhengig av foreldre. At vekten på utøvelsen, og tilhørigheten til sin tradisjon, er en naturlig tolkning av CRC, bekreftes av Maria Klasson Sundin i hennes avhandling om barnekonvensjonen og religionsfriheten:

Religionsfriheten ses som en individuell rättighet, men de kollektiva sammanhang som barnet lever $i$, familjen och den kulturella grupp de tilhör, tillmäts stor betygelse som formare av identitet och trygghet. Dette blir särskilt tydligt i de artiklar, utöver religionsfrihetsartikeln, som talar om religion. (Sundin. 2016. s.70.)

Barnekomiteen har i den senere tid utfordret synet på foreldrenes rett til å velge for barna sine. I den siste rapporten om hvordan CRC blir innarbeidet i Storbritannia, blir landet kritisert for at offentlige skoler starter dagen med obligatorisk morgensamling.

The Committee is concerned that pupils are required by law to take part in a daily religious worship which is «wholly or mainly of a broadly Christian character» in publicly funded schools in England and Wales, and that children do not have the right to withdraw from such worship without parental permission before entering the sixth form. ${ }^{5}$ (Barnekomiteen. 2016. Punkt 34)

Kritikken går ikke på at skolene arrangerer «worship», men at loven sier at barna må delta. Det er ikke nok for Barnekomiteen at foreldrene har frihet til å velge for barna. Komiteens råd til styresmaktene er at elevene på selvstendig grunnlag kan få velge om de vil være med eller ikke, uavhengig av foreldrenes valg (Barnekomiteen 2016. Punkt 35). Dette må sees på som et $\emptyset$ nske fra Barnekomiteen å gi barn mer medbestemmelse og selvstendig ansvar på bekostning av foreldrenes rett til å influere barnets skoledag. Denne nytolkningen av CRC har vakt en del oppmerksomhet, ${ }^{6}$ og

\footnotetext{
4 https://lovdata.no/dokument/NL/lov/1999-05-21-30/KAPITTEL 8\#KAPITTEL 8

5 I England begynner barna på skolen i fem-årsalderen. «6th form» vil da være det året de fyller elleve år. Her kan det nevnes at norsk lov ikke gir barna denne retten før de er femten år.

6 Se for eksempel : http://www.politics.co.uk/opinion-formers/bha-british-humanist-association/article/un-children-srights-committee-calls-for-end-to-compulsory-w eller: http://www.secularism.org.uk/news/2016/06/un-childrens-rightscommittee-calls-on-uk-to-abolish-compulsory-worship-in-schools eller fra den andre siden: http://www.charismanews.com/ world/58109-taking-kids-to-church-violates-their-human-rights-says-un
} 
det siste ord er neppe sagt i dette spørsmålet. Det er også for tidlig å vite hvordan myndighetene i Storbritannia reagerer på rådet fra Barnekomiteen. Men det aktualiserer spørsmål om når barnet er modent nok til å velge selv.

\section{Den Europeiske menneskerettskonvensjonen}

Europarådet vedtok Den europeiske menneskerettskonvensjonen i 1950. Den europeiske menneskerettsdomstolen i Strasbourg håndhever konvensjonen. Artikkel 9 ligner UDHRs artikkel om religionsfrihet. Også retten til undervisning er med. I et tillegg (protokoll) til konvensjonen er retten til utdanning beskrevet. I artikkel 2 står det:

Ingen skal bli nektet retten til utdanning. Funksjoner staten påtar seg i utdanning og undervisning, skal den utøve med respekt for foreldres rett til å sikre slik utdanning og undervisning i samsvar med deres egen religiøse og filosofiske overbevisning. (Europarådet 1952)

Også her gis foreldrene rett til å bestemme over utdanningen, også den religiøse.

\section{FNS KONVENSJON OM $\emptyset$ KONOMISKE, SOSIALE OG KULTURELLE RETTIGHETER ${ }^{7}$}

Denne FN-konvensjonen gjentar og utdyper foreldreretten knyttet til utdanning av barna. I artikkel 13 gjentas foreldrenes rett til «å sikre sine barn en religiøs og moralsk undervisning i samsvar med deres egen overbevisning».

\section{FNs konvensjon om sivile og politiske rettigheter ${ }^{8}$}

Denne konvensjonen gjentar også UDHR. Den er mer ordrik om det å velge: Enhver skal ha rett til tankefrihet, samvittighetsfrihet og religionsfrihet. Denne rett skal omfatte frihet til å bekjenne seg til eller anta en religion eller tro etter eget valg (artikkel 18). Religionsfrihet innebærer rett til: å utøve sin religion eller tro gjennom gudstjeneste, iakttagelse av religiøse skikker, andaktsøvelser og undervisning. Avsnitt nr. fire i artikkelen lyder: Konvensjonspartene forplikter seg til å respektere foreldres ... frihet til å sørge for sine barns religiøse og moralske oppdragelse $i$ samsvar med deres egen overbevisning. Her er 'utdanning' skiftet ut med 'oppdragelse', og det er poengtert at det er foreldrenes rett å oppdra barna i samsvar med egen overbevisning. (FN 1966.)

\section{FN-resolusjon om religiøs diskriminering}

FNs Declaration On The Elimination of All Forms of Intolerance And of Discrimination Based On Religion Or Belief er ikke med i Menneskerettsloven, men jeg tar den med fordi den sier at en oppdragelse etter foreldrenes $\emptyset$ nske er barnets rettighet: Every child shall enjoy the right to have access to education in the matter of religion or belief in accordance with the wishes of his parents ... the best interests of the child being the guiding principle. (FN 1981.)

\section{Barnets rett til «sin religion»}

Vi har nå sett at menneskerettighetskonvensjonene er tydelige på at alle, også barn, skal ha religionsfrihet. De er samstemte om at foreldre skal velge hvilken tro barna skal

\footnotetext{
7 Den internasjonale konvensjonen om økonomiske, sosiale og kulturelle rettigheter ratifisert 16. desember 1966. (https://lovdata.no/dokument/NL/lov/1999-05-21-30/KAPITTEL_4\#KAPITTEL_4)

8 Den internasjonale konvensjonen om sivile og politiske rettigheter med protokoller. Vedtatt 16. desember $1966 \mathrm{https}: / / \mathrm{lov}$ data.no/dokument/NL/lov/1999-05-21-30/KAPITTEL_6\#KAPITTEL_6
} 
oppdras i. Det lille barnets religionsfrihet blir en rett til å utøve 'sin religion' mer enn å velge livssyn. Friheten til å velge kommer senere $\mathrm{i}$ barnets liv, når det er modent nok til å ta et slikt valg. CRC sier det er foreldrenes plikt å veilede barna om utøvelse av sine rettigheter, herunder også religionsfriheten.

Også Julia Köhler-Olsen kommer i sin avhandling om barns religionsfrihet fram til at barnets religionsfrihet ikke er en rett til å velge selv uavhengig av modenhet og alder: Barnekonvensjonen har ingen bestemmelse om barnets rett til selvbestemmelse (Köhler-Olsen 2011. S. 540).

Hun er på linje med Sylvie Langlaude som i sin bok om barns religiøse rettigheter i internasjonal lov skriver:

The legal right of the child to religious freedom is the right of every child to be unhindered in their growth as an independent autonomous actor in the matrix of parents, religious community and society. (Langlaude 2007. s.245.)

Maria Sundins avhandling refererer til Langlaude når hun konkluderer:

Langlaude har en viktig poäng, när hon mener at rätten att behålla en religion, med alla de relationsaspekter den innefattar, nog er viktigare för de allra flesta barn, särskilt de yngsta, än rätten att välja bort och välja nytt. (Sundin 2016. s. 177.)

Men ordlyden i CRC, sammen med artikkel 18 i UDHR, gir åpning for at barn som er modne nok, kan velge en annen religion: Köhler-Olsen fortsetter:

Gjennom å tale om foreldrenes ansvar for a veilede barnet $i$ henhold til barnets modenhet og alder når barnet utøver sin rett til tros- og livssynsfrihet, påpeker barnekonvensjonens ordlyd imidlertid at veiledningen etter alder og modenhet kan resultere $i$ at foreldrene lar barnet ta ansvaret for et selvbestemt valg. (Köhler-Olsen 2011. s 540.)

Det konvensjonene ikke tar opp, er barns rettigheter når foreldrene ikke er enige på det religiøse området. Dette er et minefelt som krever sin egen behandling.

Barnelova ${ }^{9}$ må tas med her. Den tar ikke opp religionsfriheten, men den har flere paragrafer som tar opp barns selvbestemmelse. Særlig §§ 30, 31 og 33 er aktuelle. Fokus for $\S 30$ er foreldrenes retter og plikter. § 31 fokuserer på barnets rett til innflytelse på egen situasjon:

Eit barn som er fylt sju år, og yngre barn som er $i$ stand til å danne seg eigne synspunkt, skal få informasjon og høve til å seie meininga si før det blir teke avgjerd om personlege forhold for barnet ... Meininga til barnet skal bli vektlagt etter alder og modning. Når barnet er fylt 12 år, skal det leggjast stor vekt på kva barnet meiner (Barnelova § 312 ledd).

I 2014 ble det som nevnt innført et eget kapittel om menneskeretter i Grunnloven. $\S 104$ lyder:

Barn har krav på respekt for sitt menneskeverd. De har rett til å bli hørt i spørsmål som gjelder dem selv, og deres mening skal tillegges vekt $i$ overensstemmelse med deres alder og utvikling.

Paragrafene i Barnelova og Grunnloven gir ikke barn ansvaret, men innflytelse over eget liv. Ansvaret ligger fortsatt hos de voksne. Barnelova viser, slik KöhlerOlsen påpeker, at veiledningen skal tilpasses modenheten fram til barna er religiøst myndige.

9 Lov om barn og foreldre (Barnelova) fra 1981. 
Loven om trossamfunn ${ }^{10}$ regulerer norske barns tilhørighet til trossamfunn. Barn blir ved fødselen automatisk tilhørende det trossamfunnet foreldrene tilhører. Hvis foreldrene ikke er gift, er det morens tilhørighet som blir barnets tilhørighet ( $§$ 5).

\section{Konklusjon}

Barn har religionsfrihet. Men foreldrene har retten til å velge religiøs oppdragelse for barnet. Små barns religionsfrihet er først og fremst retten til å beholde, utvikles i og utøve sin religion, men også etter hvert som de blir eldre, muligheten til å velge annerledes enn foreldrene. Menneskerettene, og norsk lov, regner barnets religion som den de er født inn i. Barnets rett blir da å få utvikle også sine åndelige sider i den konteksten de hører til. Barnelova § 31 og CRC artikkel 14 gir foreldrene ansvar for å sørge for barnets aktive deltagelse og å ta mer og mer hensyn til barnets egen mening etter hvert som det vokser til. Juridisk skjer ansvarsoverdragelsen til å bestemme tro selv ved 15 år. (Lovdata 1981 og 1996.)

Denne forståelse av religionsfrihet er, som vi har sett i diskusjonen mellom Hasle og Brun-Pedersen, ikke ubestridt. Konvensjonene i sin nåværende form er forpliktende for Norge. Men formuleringene i konvensjonene er vage nok, og Barnekomiteens uttalelser sprikende nok, til at det er viktig å ta en diskusjon om dette.

\section{Del II: Kan EN ReligiøS \\ OPPDRAGELSE VÆRE TIL BARNETS BESTE?}

Norge er et samfunn med sterkt fokus på individuelle verdier, ${ }^{11}$ også barns. Et utslag av dette er diskusjoner om foreldre bør oppdra sine barn i den tro de selv har eller ikke. Slik jeg har tolket lovverket, blir en oppdragelse i samsvar med foreldrenes religion sett på som et gode og en rett for barnet slik deklarasjonen fra 1989 utrykker det tydeligst. Men det påpekes at «barnets beste» skal være «The guiding principle» (FN, 1989). Jeg vil avgrense meg til à diskutere situasjonen i hjem der foreldre har et livssynsmessig engasjement, og der de er samstemte.

Jeg vil i det følgende diskutere tre behov som foreldre bør tilfredsstille, og som jeg mener vanskelig kan møtes uten å involvere livssyn. Derfor blir den avsluttende konklusjonen at foreldre, ut fra hensynet til barnets beste, kan oppdra sine barn i det livssyn de mener er best. Dette gjelder både kristne og muslimer, human-etikere og overbeviste ateister. Brun-Pedersen (sitatet innledningsvis) argumenterer riktig nok for en livssynsnøytral oppdragelse ${ }^{12}$, men han mener at foreldre skal påvirke barna verdimessig. Dette forutsetter samtale og svar på barns «hvorfor?», og da kommer en ikke utenom livssynstilknyttede argumenter. En nøytral oppdragelse må møte humanistiske tanker og verdier med samme holdning og samme avstand som religiøse

10 Lov om trudomssamfunn og ymist anna. Trådte i kraft 1. januar 1970.

11 Se for eksempel: Nafstad, H.E. 2005. Forholdet mellom individualisme og fellesskap: En utfordring for positiv psykologi. I Psykologi, Tidsskrift for norsk Psykologforening. Utgave 10. 2005. http://www.psykologtidsskriftet.no/index.php?seks id=305119\&a=3 (Lest 25.april 2016.) Her peker Nafstad på at utviklingen av språket i Norge tyder på at individualistiske verdier er økende.

12 Brun-Pedersen bruker ikke begrepene 'livssynsnøytral' i sitt svar til Hasle, selv om hans argumentasjon godt kan forstås som et ønske om en slik oppdragelse. I innlegget som står nedenfor svaret til Hasle på Brun-Pedersen sin innleggside på nettstedet Verdidebatt, bruker han «livssyns-nøytral» og setter det opp mot begrepet 'verdinøytral'. Han anklager redaktør Simonnes i Vårt Land for ikke å forstå forskjellen. Det er derfor ikke unaturlig å bruke disse begrepene også i denne artikkelen.(Brun Pedersen. 2014b) 
tanker og verdier. Et «ikke-teistisk» svar er ikke mer livssynsnøytralt enn et teistisk.

Ett moment som er svært viktig å understreke, er at konklusjonen om at en oppdragelse i foreldrenes livssyn kan være til barnets beste, ikke fritar foreldrene fra en kritisk vurdering av hva som kan være en sunn eller usunn religiøs oppdragelse. Det har vært en del fokus på usunn religiøsitet, og det er et viktig fokus også foreldre må ha i forhold til sin egen praksis. Foreldre kan ikke gjemme seg bak foreldreretten hvis oppdragelsen ikke bygger barnets autonomi, eller er psykisk skadelig. Dette spørsmålet er det ikke rom for å behandle nærmere i denne artikkelen. Likevel vil artikkelen avsluttes med noen vurdering-er om hvordan en religiøs oppdragelse til barnets beste kan være en oppdragelse som oppmuntrer til selvstendighet og en reflektert holdning til livet.

\section{《BARNETS BESTE»: $\AA$ FÅ EN OPPDRAGELSE KNYTTET TIL FORELDRENES TRO?}

I Barnekonvensjonen, CRC, er det en hovedsak at barns beste er å få utvikle alle sine evner på en best mulig måte. Mine refleksjoner rundt spørsmålet om religiøst aktive eller tilbaketrukne foreldre er det beste for barna, vil i hovedsak derfor følge tre temaer knyttet til barns behov for:

1 Sosial utvikling - Tilhørighet.

2 Psykisk og moralsk utvikling - Hjelp til å bearbeide sine eksistensielle spørsmål.

3 Åndelig utvikling.

Disse temaene er utledet av formuleringer som er gjentatt flere steder i CRC, om at konvensjonen på forskjellig vis ønsker å fremme barns «fysiske, psykiske, ånde- lige, moralske og sosiale utvikling» (Se f.eks: Art 32,1, art 17, art 27,1, art 29,1). Den fysiske utviklingen blir ikke behandlet i denne artikkelen. Om den sosiale utviklingen mener CRC at tilhørighet til familien og familiemiljøet (se innledningen punkt $5 \mathrm{og}$ 6) er en avgjørende faktor. Til en psykisk og moralsk utvikling knytter jeg særlig evnen til å møte livets utfordringer. Det betyr en evne til å tenke gjennom eksistensielle spørsmål omkring mening, moral og forholdet til andre mennesker. Barns rett til åndelig utvikling blir gjentatt i flere artikler.

\section{Barn har behov for tilhørighet}

Tilhørighet og deltagelse er viktig i barnets identitetsbygging og sosiale utvikling. En viktig kritikk mot CRC og Barnekomiteen er at den har et for ensidig fokus på enkeltindividets rettigheter, og slik løsriver barnet som religiøst subjekt fra de grunnleggende enhetene som omgir det, familien og trosfellesskapet. (Adhar \& Leigh. 2005 s.217.)

Denne kritikken kan synes urettferdig i henhold til fokuset på familien, som er en hovedsak i CRC, men berettiget i forhold til familiens plass i litt større fellesskap. Julie Köhler-Olsen henviser i sin avhandling til Sylvie Langlaude:

Etterå ha analysert hvilken betydning livssynsfrihet, familie og trossamfunn har i et barns liv, konkluderer hun med at barnets rett til trosog livssynsfrihet er basert på barnets interesse av å kunne utvikle seg uhindret til en uavhengig, autonom person i matrisen bestående av barnets foreldre, trossamfunnet og samfunnet. (Köhler-Olsen. 2011. s. 198.)

Barns identitetsdannelse er nært knyttet til tilhørighet. Barnets opprinnelige tilhørighet er ikke noe det velger. Det er noe det oppdager. Ordet 'identitet' kommer av 
det latinske ordet «idem» som betyr 'det samme'. En del av denne samkjenslen er å gjenkjenne noe ved andre som er 'det samme' som meg.

Barn begynner sin utvikling gjennom å kopiere foreldrene. Deres ord, handlinger og holdninger. Det er en av grunnene til at Barnekomiteen legger vekt på foreldrenes forbilde når de skal veilede barna $\mathrm{i}$ utøvelsen av deres rettigheter (se avsnittet "Barnekonvensjonen» ovenfor). $\AA$ utelate sider av livet som er viktige for foreldrene, er å stenge barna ute fra noe av dette viktige identitetsskapende fellesskapet. Små barn spør ikke: Hvem er jeg?, men: Hvem er vi?

For religiøst aktive familier er ofte det religiøse fellesskapet med på å definere familien. Hvis foreldrene sier: «Dette fellesskapet er meningsfullt og viktig for meg, men jeg vil ikke at du skal være en del av det før du kan bestemme selv», er, med en litt søkt sammenligning, som om iherdige orienteringsløper-foreldre skulle si: $\ll \AA$ løpe ut i skog og mark gir oss de beste opplevelsene, men vi vil ikke ta deg med, i tilfelle du heller vil satse på fotballen.» Spørsmålet om tilhørighet gir argument for at livssynsmessig aktive foreldre involverer barna i sine fellesskap og lar dem delta i disse. At foreldrene lar barn få delta i de sammenhengene foreldrene hører til i, også de religiøse, er viktig for den sosiale utviklingen og gir mulighet for foreldre til å utøve sin forbilde-funksjon.

\section{Barna og de eksistensielle spørsmålene}

Vår kultur er blitt bevisst på at barn arbeider med eksistensielle spørsmål. En følge er at å filosofere med barn er blitt vanlig i sko- ler og i barnehager ${ }^{13}$. Filosofiske samtaler fokuserer på at barn skal tenke selv, men er initiert og fasilitert av voksne. Barn er nysgjerrige på hva de voksne mener, og de forventer å få ærlige svar. Hvis de voksne ikke vil fortelle, blir det som om slike spørsmål ikke bør snakkes om.

Religionspedagogen Friedrich Schweitzer argumenterer i sin bok Barns ret til religion for at barn trenger å arbeide med eksistensielle spørsmål. Han identifiserer fem spørsmål som barn er opptatt av, og som er viktige å bearbeide for en sunn personlig utvikling. Det er spørgsmål, som børn enten stiller oss, eller som vi selv bliver konfronteret med $i$ opdragelsen. Og det er «store spørgsmål» fordi de i det mindste potentielt, krcever et religiøst svar. (Schweitzer. 2006 s.30.)

Schweitzers store spørsmål er:

1 Hvem er jeg, og hvem får jeg lov til at vare? Spørgsmålet om mig selv

2 Hvorfor skal du dø? Spørgsmålet om meningen med det hele

3 Hvor finder jeg beskyttelse og tryghet? Spørgsmålet om Gud

4 Hvorfor skal jeg behandle andre rettfordigt? Spørgsmålet om grundlaget for etisk handling

5 Hvorfortrormange børnpåAllah? Spørgsmålet om de andres religion (ibid.s.31-39)

Schweitzer presenterer tre kriterier for at disse spørsmålene er viktige. For det første at spørsmålene er knyttet til barns erfaring og oppvekst. Det er ikke temaer som barn får utenfra. For det andre er det, som vi ser fra sitatet ovenfor, viktig at disse spørsmålene krever et religiøst svar. Med det mener ikke Schweitzer at svaret må være hentet fra en religion. Men at de ikke kan besva13 Se for eksempel oppslag i Aftenposten. http://www.aftenposten.no/fakta/innsikt/Filosofi-for-de-minste-6583196.html. I
grunnskolen er filosofi og etikk et hovedområde i KRLE-faget. 
res tilfredsstillende uten livssynsmessige vurderinger. Det tredje kriteriet går på hvor viktig disse spørsmålene er for barna. Hva skjer med barn der disse spørsmålene blir forbigått i stillhet? I boka argumenterer han for at de fem spørsmålene fyller kriteriene. Etter å ha diskutert de to første kriteriene skriver han om det siste:

Desuden er det blevet klart, at disse spørgsmål ikke kan forbigås - i hvert fall ikke, hvis man skal tilgodese barnets ve og vel og give en ansvarlig opdragelse, (ibid. s. 40.)

I sin bok The Spirit of the Child konkluderer David Hay og Rebecca Nye omtrent tilsvarende.

Nye samtalte med barn om livet, og oppdaget at barn har behov for å snakke om åndelige/eksistensielle spørsmål, men at mange opplever at de voksne vegrer seg. De voksnes motvilje har negativ innvirkning:

«In a society in which the public face is one of alienation from spirituality, it is very often seen as an embarrassment, not to be talked about or even admitted to oneself. As a result the initial breadth of a person's insight often dwindles down and becomes constricted to little more than a source of private comfort in times of distress.> (Hay og Nye. 2006.loc 268-269.)

Schweitzers og Hay/Nyes forskning og resonnement viser at det er viktig for barn å snakke med og få veiledning av voksne om eksistensielle spørsmål. Hvis de voksne i en slik samtale skal være livssynsmessig nøytrale, kan de ikke si stort annet enn: 'Hva mener du selv?' Dette er et godt og viktig spørsmål, men barna må få lov til å stille det samme spørsmålet tilbake. Barn trenger voksne som kan diskutere de eksistensielle spørsmålene med dem, og som kan være forbilder også i det å gjøre seg opp en mening.

\section{Barna og åndeligheten}

Hay og Nye bruker uttrykket «relational consciousness» om barns åndelighet. Det dreier seg om en bevissthet om å stå i relasjon til seg selv, til andre, til verden omkring og også til Gud eller en virkelighet utenfor det fysiske (Hay and Nye 2005.loc 1275).

David Hay skriver om opphavet til denne åndeligheten :

«I have also presented a notion of spirituality as something biologically built into the human species, an holistic awareness of reality which is potentially to be found in every human being.> (Hay \& Nye 2005:63)

Justin Barret og Roger Trigg, begge professorer ved universitetet i Oxford, ledet en gruppe på 57 forskere som over 3 år gjennomførte 40 studier rundt om i verden for å kartlegge barns religiøsitet. Trigg konkluderer i et intervju med Oxford universitets informasjonsavdeling:

We have gathered a body of evidence that suggests that religion is a common fact of human nature across different societies. ... human thought seems to be rooted to religious concepts, such as the existence of supernatural agents or gods, and the possibility of an afterlife or pre-life. (University of Oxford. 2011)

Tro på en åndelig verden ikke er noe som er pådyttet barn. Det å tro på en skapergud er barns biologiske «default value». Men de trenger veiledning. Justin Barret sier det slik:

Children know humans are not behind the order so the idea of a creating god (or gods) makes sense to them. Children just need adults to specify which one. (Barrett. 2008)

Barn har åndelige erfaringer og forståelse 
av virkeligheten som har religiøse implikasjoner. De trenger voksne som kan gi erfaringene og forståelsen retning. Avhengig av foreldrenes tro kan en slik veiledning befeste en tro på en gud, eller den kan la barna forstå at en slik skapertro er en naturlig del av det å være barn, og at det er like naturlig å vokse ut av en slik tro etter hvert som en modnes. Det som ikke er til det beste for barna, er voksnes motvilje mot å snakke om det åndelige. Dessverre kan det ut som at det er slik for mange. David Hay skriver: The adult world into which our children are inducted is more often than not destructive to their spirituality (Hay and Nye (2006) loc. 293). Hvis Hay har rett, er det mange barn som blir fratatt sin rett til utvikling av sine åndelige sider.

\section{Et språk for åndelighet og eksistensielle spørsmål}

Skal vi møte barns behov for samtale om eksistensielle spørsmål, trenger vi språk. Men språk er ikke nøytralt. Hvert livssyn har sitt eget ordforråd. Hvis en skal snakke om hva mennesket er og hvor mennesket kommer fra, kan en bruke ord knyttet til kristen tro, som: Gud, skapelse, i Guds bilde, nåde, frelse. Men en kan også bruke ord fra en humanistisk forståelse. Da vil: utvikling, respekt, sekulær, naturlov, tilfeldighet, likeverd, skape mening etc. være mer sentrale begreper. Et språk som unngår begrepet «gud», og orienterer seg utelukkende ut fra mennesket, er ikke mer nøytralt enn et språk som inkluderer slike ord.

Rebecca Nyes arbeid dreide seg om hva slags språk barna hadde som verktøy i arbeidet med det eksistensielle. De fleste barna hentet ord fra de religiøse språkene, også barn som ikke kjente betydningen av dem: We have seen that even highly secula- rized children resort to religious language to express their spiritual insights (Hay and Nye 2006. Loc 1922). Noen brukte andre språk. Nye kategoriserer ni forskjellige områder barna henter vokabular fra: fra lek og spill, via naturen og vitenskapelig språk til vokabular om tid og sted. Noen språk fungerer bedre enn andre. Men poenget her er ikke at ordforråd hentet fra religiøst språk eller lekens språk fungerer bedre i samtalen om eksistensielle spørsmål enn andre. Poenget er at språket ikke er nøytralt. Barna prøver å finne språk for åndelighet som kan godtas.

Many of these languages offer 'legitimate' ways of expressing the otherwise 'illegitimate' stuff of spirituality in a predominantly materialist, secular, rationalist culture. (Hay and Nye. 2006. Loc. 1462)

Denne trangen viser at det er til barnets beste å snakke om åndelige emner. Men da trengs ord for å snakke om døden, verdiene og meningen med livet; et språk som hjelper oss å gi uttrykk også for det åndelige, og da er det ikke nøytralt. Om vi er klar over det eller ikke, vil språket vi bruker, reflektere vårt livssyn.

\section{Hvordan kan foreldre som gir sine barn en livssynsmessig tydelig oppdragelse, samtidig gi barna frihet til å velge livssyn selv?}

Ut fra det som er kommet fram, er det naturlig å hevde at foreldre kan være tydelige på sin tro også i oppdragelsen av barnet. Det betyr ikke at all livssyns-tydelig oppdragelse er sunn. Alle med sterke meninger står i fare for å være manipulerende og ensidige. Det er altfor mange eksempler på at livssynsivrige foreldre ikke gir en opp- 
dragelse som fremmer autonomi. Unge og gamle har de siste årene tatt offentlig avstand fra en oppdragelse som har vært invaderende og skadelig for dem ${ }^{14}$. Enhver oppdragelse bør fremelske og respektere barns selvstendighet. Den siste delen av artikkelen skal derfor peke på hvordan en religiøs oppdragelse kan fremme barnas religiøse frihet og gjøre barna i stand til å ta et selvstendig valg når de er modne til det. Dette er også avgjørende viktig for barnas mentale helse.

Den åndelige/religiøse modenheten er forskjellig fra annen intellektuell modenhet. Det er ikke nok å lære kritisk tenkning og generell selvstendighet for å fremme religiøs/livssynsmessig selvstendighet. James Fowler har utarbeidet den mest kjente teorien om barns religiøse utvikling (Fowler, 1995. Part 18). Han hevder at én forskjell mellom den religiøse utvikling-en og annen utvikling er at den religiøse kan stoppe opp hvis den ikke blir stimulert. Og at mange stoppet opp før fase fire ${ }^{15}$. Der går de fra å godta gruppens meninger til selv å tenke igjennom de vanskelige spørsmålene ${ }^{16}$. De som når denne modenheten $\mathrm{i}$ fase fire, kan se kritisk også på egen overbevisning, de kan gi uttrykk for usikkerhet fordi de innser at systemet de har stolt på, har paradokser. For dem som når denne mindre selvsikre fasen, vil autoritetene, sammen med egne vurderinger og kritisk blikk, bestemme livssynsmessig overbevisning. De som ikke får utviklet den åndelige modenheten, vil, hvis Fowler har rett, kanskje aldri utvikle muligheten til autonome religiøse valg.

\section{Del III: Hvordan SER EN SLIK OPPDRAGELSE UT?}

Hvordan kan foreldre gi en oppdragelse som hjelper barna i utøvelsen av sine rettigheter? Jeg vil trekke fram fire aspekter ved oppdragelsen som fremmer barnas evne til selvstendige valg på det livssynsmessige området. Det første er at barna får oppleve at de åndelige spørsmål blir tatt på alvor. Dette gjelder både positivt søkende og kritiske spørsmål. En oppdragelse til livssynsmessig modenhet må oppmuntre barns eksistensielle refleksjon, og «belønne» barns fors $\emptyset \mathrm{k}$ på å formulere sine tanker og erfaringer med interesse og alvor fra de voksne. Det betyr at voksne lytter like mye som de forklarer. Voksne må være forsiktige med å latterliggjøre barns originale fors $\emptyset \mathrm{k}$ på å beskrive sine tanker. $\AA$ bli tatt på alvor, også når den eksistensielle refleksjon er dypere enn barnets evne til å formidle, er en forutsetning for at barn tør å sette ord på tankene sine.

Det andre aspektet jeg vil trekke fram, er de voksnes reaksjon på barns tvil og vanskelige spørsmål om sin tro. Barn trenger voksne som har kommet videre fra en ureflektert avhengighet av autoritet eller gruppe. De kan hjelpe barn med den samme modningsprosessen. Tvil og undring er nødvendig for refleksjon. Det er godt å få

\footnotetext{
14 Ett eksempel er Anders Torps bok Jesussoldaten. Han beskriver det han opplevde som en skadelig oppdragelse. I omtalen av NRKs program om møtet mellom far og sønn brukes ordet tortur om elementer i Anders’ oppvekst. (https://www.nrk.no/ norge/sterkt-mote-mellom-far-og-sonn-torp-1.12860506) (Lest 21. september 2016)

15 let us remember that many adults do not construct it and that for a significant group it emerges only in the mid-thirties or forties. (Fowler 1995.s 182)

16 Fowler kalte tredje trinn for den syntetisk-konvensjonelle perioden. Den religiøse trangen i denne perioden er å få system på det religiøse innholdet. En slutter seg til det tros-system som gjelder i sin gruppe. Den fjerde perioden er den individuativrefleksive. I stedet for å slutte seg til gruppens tro reflekterer en over troen og sin egen holdning til denne (Fowler 1995).
} 
svar på spørsmål, men det er også godt å få en bekreftelse på at vanskelige spørsmål er nettopp det; vanskelige. Det kan være like nyttig å undre seg sammen over livets mysterier og utfordringer som å gi svar. Det kan gjøre det lettere for barnet å ta opp nye temaer det grubler på. Jeg har møtt barn som holder det vanskelige inni seg for å beskytte de voksne. Barn må få vite at de voksne tåler det de har å komme med. $\mathrm{Og}$ de trenger å erfare at det er mulig å ha en overbevisning også selv om en ikke har svar på alle spørsmål.

Det tredje jeg vil trekke fram som viktig i prosessen mot en selvstendighet og autonomi, er at barna etter hvert som de blir eldre, får oppleve reelle valgmuligheter. Vi kan bruke møte-deltagelse som eksempel. Små barn i religiøse familier blir tatt med til kirke, moskeer eller møter. De kan ikke være alene hjemme. Det er en del av oppdragelsen å bli trygg på hvordan det er å være på slike tilstelninger og få ta del i familiens trosliv. Når barnet er eldre, kan det etter hvert få mulighet til å velge. Dette betyr ikke at foreldre ikke kan være tydelige på at de $\emptyset$ nsker deltagelse. Foreldres uttalte $\emptyset$ nske for barnet er en viktig del av oppdragelsen. Men friheten til å velge annerledes er også viktig. Og jo eldre de blir, jo større $b ø r$ denne valgfriheten være. For eksempel bør alle konfirmanter, også fra aktive kristne hjem, få et åpent spørsmål om de $\emptyset$ nsker å konfirmere seg.

Det siste jeg vil trekke fram, er forholdet til «de andre». En viktig del av identitetsbyggingen er opplevelsen av å høre til i en gruppe. Små barn vil oppleve familiens livssyn som en selvfølge. Men før eller siden oppdager de at andre har annen tro enn dem. De spør: «Hvorfor er ikke alle muslimer?» Eller: «Hvorfor tror noen på
Gud?» Å bli kjent med, snakke sant om og behandle mennesker med andre livssyn med respekt er avgjørende for at barn kan orientere seg i samfunnet. Det er en viktig del av modningen å kunne reflektere over forholdet mellom eget og andres livssyn. $\AA$ kunne se likheter og forskjeller, styrker og svakheter ved eget og andres livssyn er en viktig del av prosessen mot selvstendighet.

\section{KonKLUSJON}

Vi har i denne artikkelen sett at det er en rimelig forståelse av de menneskerettskonvensjonene Norge har ratifisert, at religionsfrihet for barnet betyr frihet til å få en oppdragelse i samsvar med foreldre/foresattes religiøse overbevisning og ønske. En slik oppdragelse kan også være i tråd med hensynet til barnets beste, fordi den åpner for viktig identitetsbygging og en vekst $i$ forhold til barns evne til å reflektere over åndelige erfaringer og eksistensielle spørsmål. En aktiv religiøs oppdragelse er ikke en motsetning til barnets religiøse autonomi, men kan fremme en åndelig utvikling som muliggjør at barnet, når det er modent nok, på selvstendig grunnlag kan ta sitt eget valg.

\section{LitTeratur}

Barnekomiteen (Committee on the Rights of the Child). 2005. GENERELL KOMMENTAR NR. 7 (2005) Gjennomføring av barnets rettigheter i tidlig barndom. https://www. regjeringen.no/globalassets/upload/bld/ barnets-rettigheter/generell-kommentar-7.pdf (Lest 12.juni 2016)

Barnekomiteen (Committee on the Rights of the Child). 2016. Concluding observations on the fifth periodic report of the United Kingdom of Great Britain and Northern Ireland. http://www.crae.org.uk/media/93148/ 
UK-concluding-observations-2016.pdf (Lest september 2016).

Barrett, Justin L. 2008. Out of the Mouths of Babes. The Guardian-nettversjonen 25. November 2008. http://www.theguardian. com/commentisfree/belief/2008/nov/25/ religion-children-god-belief (Lest 3. mai 2016).

Brems, Eva. 2006. A commentary on the United Nations Convention on the Rights of the Child. Article 14. The Right to Freedom of Thought, Conscience and Religion. Martinus Nijhoff Publishers. Leiden.

Brun-Pedersen Jens. (2014). Foreldrerett - og barns religionsfrihet Vårt Land 23. januar 2014. http://www.verdidebatt.no/rakker/

Brun-Pedersen. Jens. (2014) Snedig om nøytralitet. Vårt Land 6. januar http://www. verdidebatt.no/rakker/

Europarådet 1950. Den europeiske menneskerettighetskonvensjon. https://www. regjeringen.no/no/dokumenter/deneuropeiske-menneskerettighetskonvens/ id88366/

Europarådet 1952: Protokoll til Konvensjonen om beskyttelse av menneskerettighetene og de grunnleggende friheter Paris 20. mars 1952 https://lovdata.no/dokument/ NL/lov/1999-05-21-30/KAPITTEL_2

FN 1966. Den internasjonale konvensjonen om økonomiske, sosiale og kulturelle rettigheter ratifisert 16 . desember 1966 . https://lovdata.no/dokument/NL/lov/1999-05-2130/KAPITTEL_4\#KAPITTEL_4

FN. 1989: FNs konvensjon om barnets rettigheter. Vedtatt: 20.11.1989. Ratifisert av Norge: 08.01.1991. https://lovdata. no/dokument/NL/lov/1999-05-21-30/ KAPITTEL_8\#KAPITTEL_8

FN. 1981. Declaration On The Elimination of All Forms of Intolerance And of Discrimination
Based On Religion Or Belief. http://www. un.org/documents/ga/res/36/a36ro55.htm

FN. 1948. FNs verdenserklaring om menneskerettigheter vedtatt 10.12.1948 http:// www.fn.no/FN-informasjon/Avtaler /Menneskerettigheter/FNs-verdens erklaering-om-menneskerettigheter

Fowler, James W. 1995. Stages of Faith: The Psychology of Human Development and the Quest for Meaning. Harper Collins publishers. New York.

Hay, David \& Nye, Rebecca. 2006. The Spirit of the Child. Revised Edition. Jessica Kingsley Publishers. London and Philadelphia. Kindle edition (Original edition published 1998)

Kilkelly, Ursula. 2016.The Child's Rights to Religious Freedom in International Law The Search for Meaning. I Fineman M. A, \& Worthington K. (Red): What is Right for Children. The Competing Paradigms of Religion and Human Rights. Først utgitt av Ashgate Publishing 2009. Versjon utgitt av Routledge 2016. New York, s.243 - 269.

Köhler-Olsen, Julie. 2011. Barnets rett til selvbestemmelse $i$ forhold til religiøse normer. Avhandling ved Juridisk fakultet Universitetet i Oslo.

Langlaude, Sylvie. 2007. The Right of the Child to Religious Freedom in International Law. International studies in Human Rights. Volume 93. Martinus Niijhoff Publishers. Leiden.

Lovdata. 1981. Lov om barn og foreldre (Barnelova). Tilgjengelig: https://lovdata.no/dokument/NL/lov/1981-04-08-7/ KAPITTEL_5\#KAPITTEL_5

Lovdata 1996. Lov om Den norske kirke (kirkeloven). Tilgjengelig: https://lovdata.no/dokument/NL/lov/1996-06-0731?q=Kirkelova 
Lovdata. 1999. Lov om styrking av menneskerettighetenes stilling i norsk rett (menneskerettsloven). Tilgjengelig: https:// lovdata.no/dokument/NL/lov/1999-0521-30

Lovdata. 2003. Barnekonvensjonen som del av menneskerettsloven. Tilgjengelig: https:// lovdata.no/artikkel/barnekonvensjonen_ som_del_av_menneskerettsloven/993

Omvik, Eirik. 2014. Sekularisering også i kristne kjernefamilier. Avisartikkel Vårt Land 21. januar 2014.
Schweitzer, Friedrich. 2006. Barnets ret til religion. Aros Forlag Frederiksberg. https:// www.sciencedaily.com/releases / 2011/07/110714103828.htm (Lest 26. april 2016).

Sundin, Maria K. 2016. Barnets religionsfrihet - en villkorad rättighet? Acta Universitatis Upsaliensis. Uppsala.

University of Oxford. «Humans 'predisposed" to believe in gods and the afterlife.» ScienceDaily. 14 July 2011. 